\title{
The antiquity of Jaffna Fort: new evidence from post-disaster archaeological investigations in northern Sri Lanka
}

Christopher Davis ${ }^{1, *}$, Robin Coningham ${ }^{1}$, Prishanta Gunawardhana ${ }^{2}$, P. Pushparatnam ${ }^{2,3}$, Armin Schmidt ${ }^{1} \&$ Mark Manuel $^{1}$

Post-disaster archaeological investigations at Jaffna Fort have revealed material demonstrating pre-colonial contact, shedding new light on the importance of the site in Indian Ocean trade and communications networks before European occupation.

Keywords: Sri Lanka, Indian Ocean, Jaffna Fort, post-disaster archaeology, maritime trade

The Dutch East India Company besieged the Portuguese fort at Jaffna in March 1658. With terms of surrender agreed on 22 June 1658, they encountered a site "battered to pieces" (Baldaeus 1703: 798) and proceeded to level or remodel damaged structures. The outer works were completed in 1792, transforming the site from a quadrangle to a pentagonal fortification (Figure 1), but the poorly provisioned Dutch garrison surrendered to British forces three years later without firing a shot (Nelson 1984: 82-83). More recently, Jaffna Fort was a strategic and symbolic focus during the conflict between the Sri Lankan Government and the Liberation Tigers of Tamil Eelam-a humanitarian catastrophe that also destroyed cultural heritage.

This heritage is now a focus for efforts to address reconciliation, renewal and peacebuilding through tourism and its associated economic impacts (Pushparatnam 2014). Conservation to date has concentrated on colonial-era structures (Mudiyanselage 2011). Recent discoveries uncovered during the construction of new visitor infrastructure, however, including Rouletted Ware (c. 200 BC-AD 200) (Tomber 2000; Ford et al. 2005) and ceramics from East and West Asia (Pushparatnam 2015: 88-90), point to both the presence of vulnerable earlier sub-surface heritage and the site's potential time-depth and place in island-wide and Indian Ocean exchange networks (Ragupathy 1987; Rajan \& Rama 1994; Begley 1996; Weisshaar et al. 2001; Coningham 2006; Carswell et al. 2013).

The 'Jaffna Fort Post-Disaster Archaeological Research Project' responded to this context in 2017 by beginning to map, identify and characterise its cultural sequences through excavation, unmanned aerial vehicle (UAV) and ground-penetrating radar (GPR) surveys (Figure 2). Transposing methodologies for post-disaster heritage co-designed in postearthquake Nepal (Coningham et al. 2018) (Figure 3), the team aimed to protect

\footnotetext{
Department of Archaeology, Durham University, South Road, Durham DH1 3LE, UK

Central Cultural Fund of Sri Lanka (CCF), Bauddhaloka Mawatha, Colombo, 07, Sri Lanka

Department of History, University of Jaffna, Thirunelvely, Jaffna, 70140, Sri Lanka

* Author for correspondence (Email: christopher.davis@durham.ac.uk)
}

(C) Antiquity Publications Ltd, 2019

ANTIQUITY 93 368, e13 (2019): 1-7

https://doi.org/10.15184/aqy.2019.30 


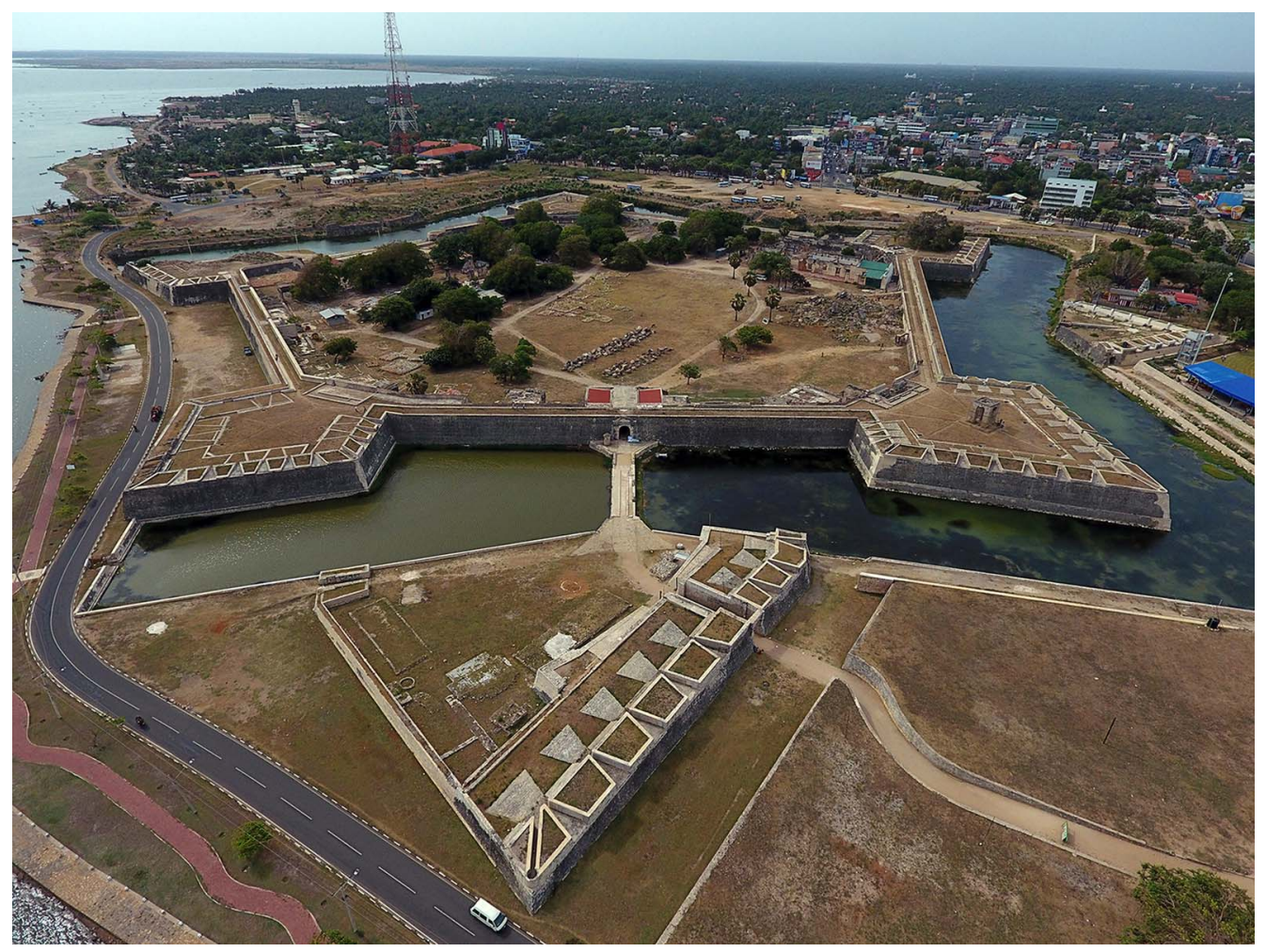

Figure 1. UAV image of Jaffna Fort, looking west.

archaeologically sensitive areas as well as refine typologies from Jaffna's first scientifically dated sequences.

GPR survey identified rectilinear anomalies below the Parade Ground (Figure 4) that may represent structures from the Portuguese Fort, including the church, 'Our Lady of Miracles', which was cleared by the Dutch. Although monuments from earlier periods were destroyed, there is a history of reincorporation with earlier tombstones and bells reinterred inside the Dutch-era Kruys Kerk and pre-colonial carved granite blocks within rubble at the site, probably recycled from Hindu temples demolished by the Portuguese (Pushparatnam 2015: 96-98).

In addition to European-produced artefacts, pre-colonial contact materials were successfully recovered, particularly from excavations close to a new septic tank (Figure 5). Black and Red Ware, Dusun Jars, Early Islamic glazed wares, Rouletted Ware and Ming porcelain were excavated from contexts without European-contact artefacts, confirming the pre-colonial significance of Jaffna Fort. Importantly, new ceramic types were identified, including sherds exhibiting rouletting and stamped radial designs, illustrating both Jaffna's uniqueness and central place within international Indian Ocean networks (Figure 6). Unfortunately, these finds were from within mixed deposits above the natural bedrock. While we await scientific dating confirmation, the terminus ante quem for the earliest phases is estimated to be the seventh or eighth century $\mathrm{AD}$, although many individual items date to the first millennium $\mathrm{BC}$. 


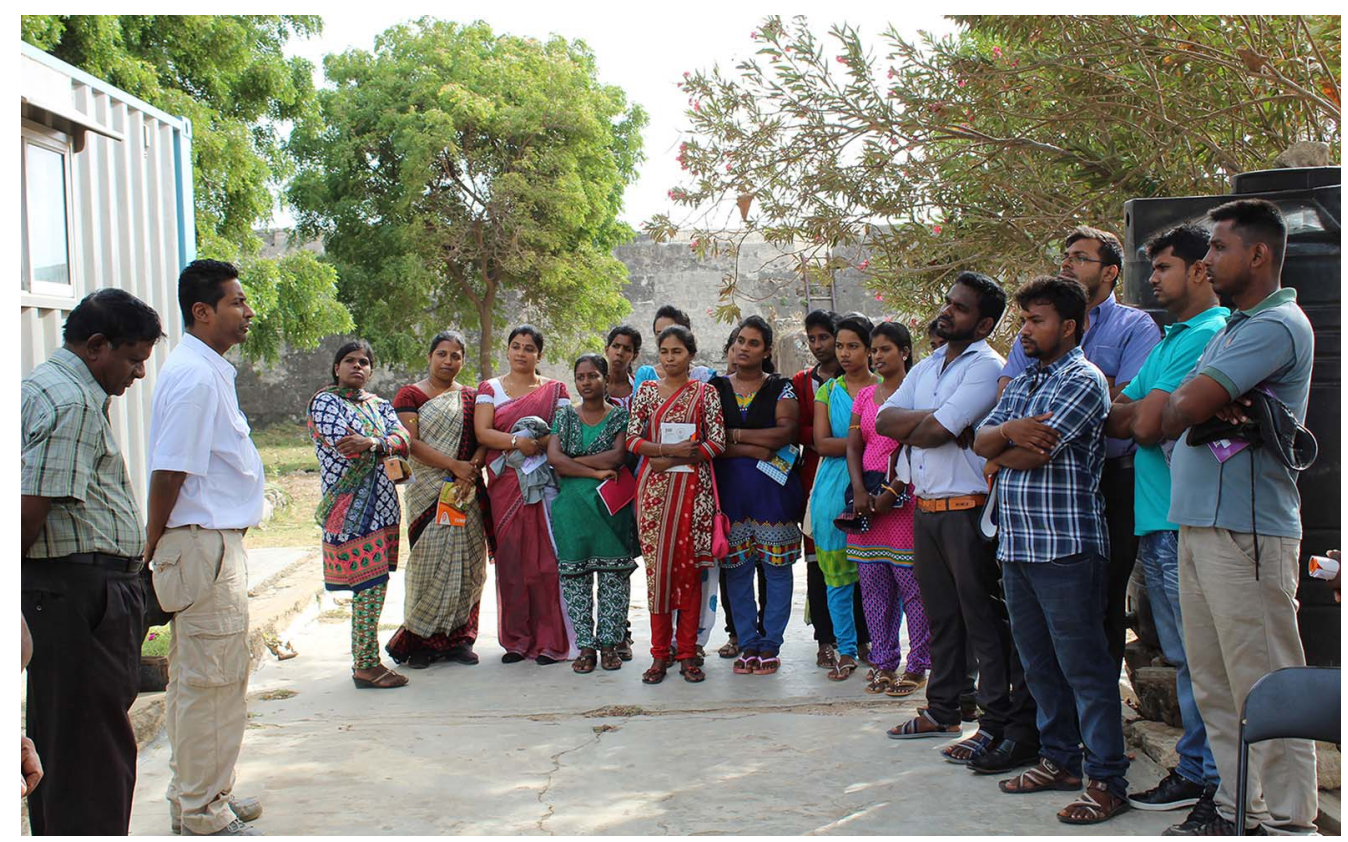

Figure 2. Professor Pushparatnam, Director, CCF Jaffna and Professor Gunawardhana, Director-General CCF, with participants from the University of Jaffna and CCF at the start of the 2017 field season.

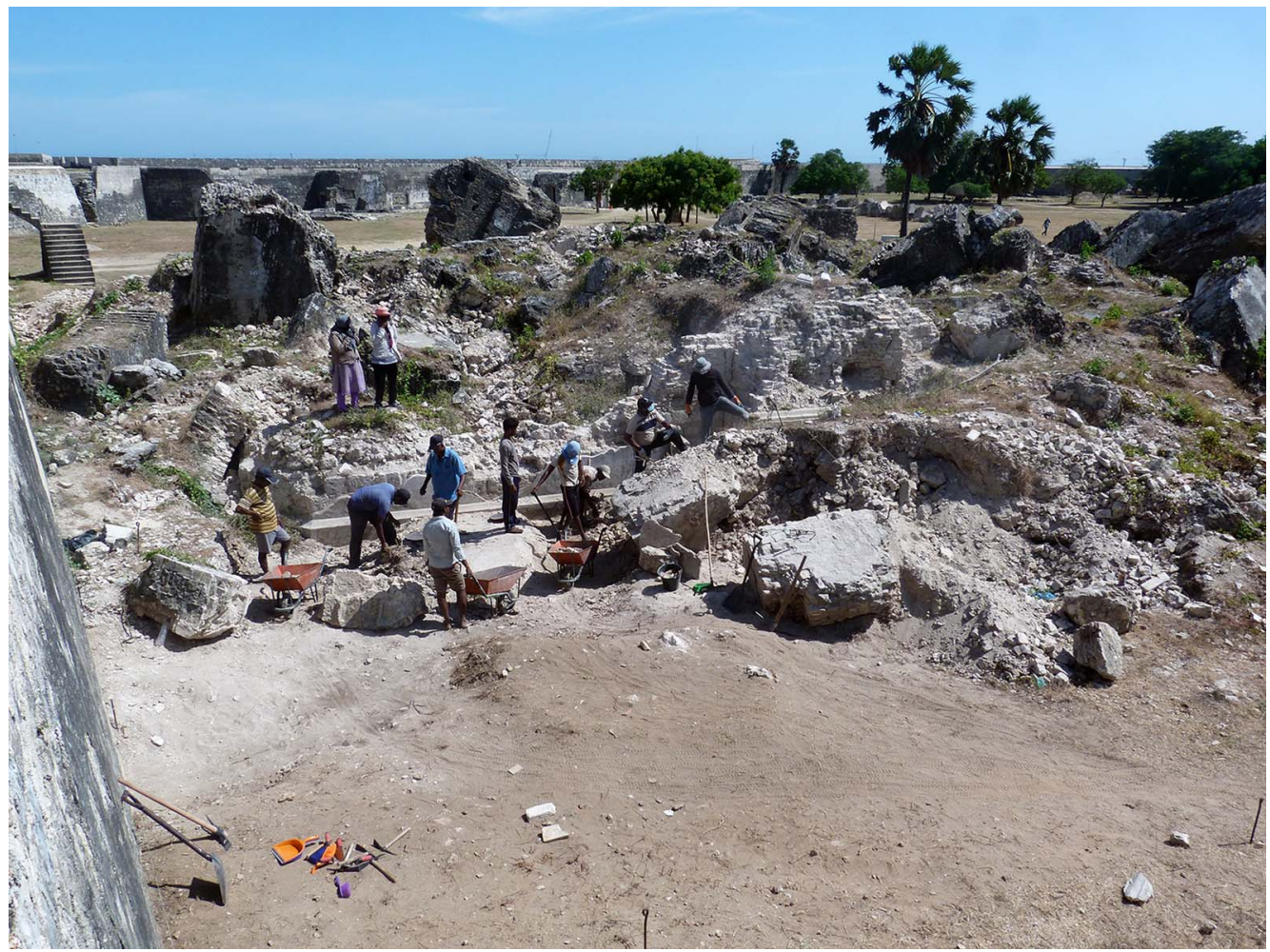

Figure 3. Post-disaster excavations at the Kruys Kerk.

(C) Antiquity Publications Ltd, 2019 


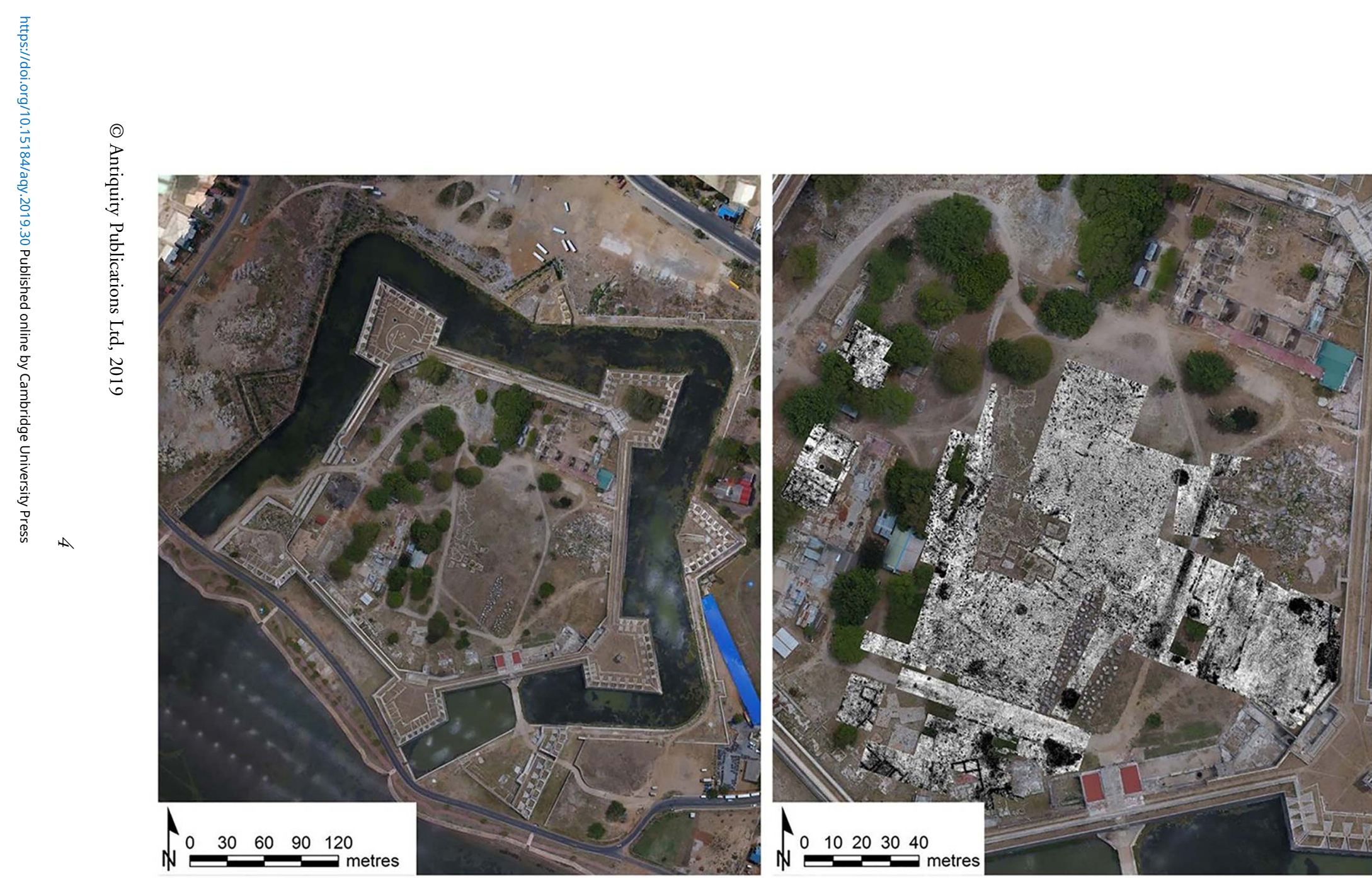

Figure 4. UAV map of Jaffna Fort (processed with Pix4Dmapper software) with GPR survey results at a depth of $0.8 m$. 


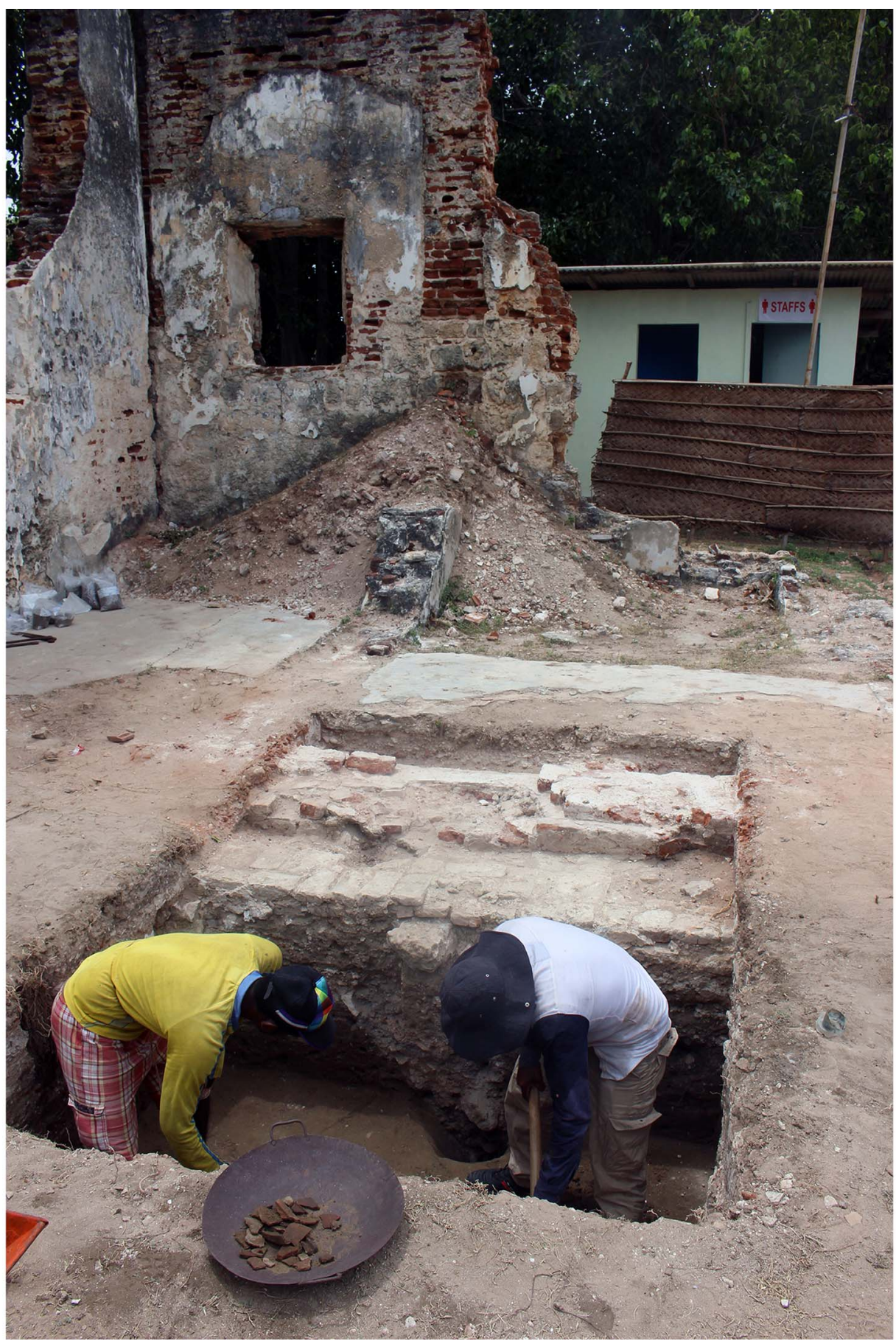

Figure 5. Excavations near the new toilet block and septic tank. 

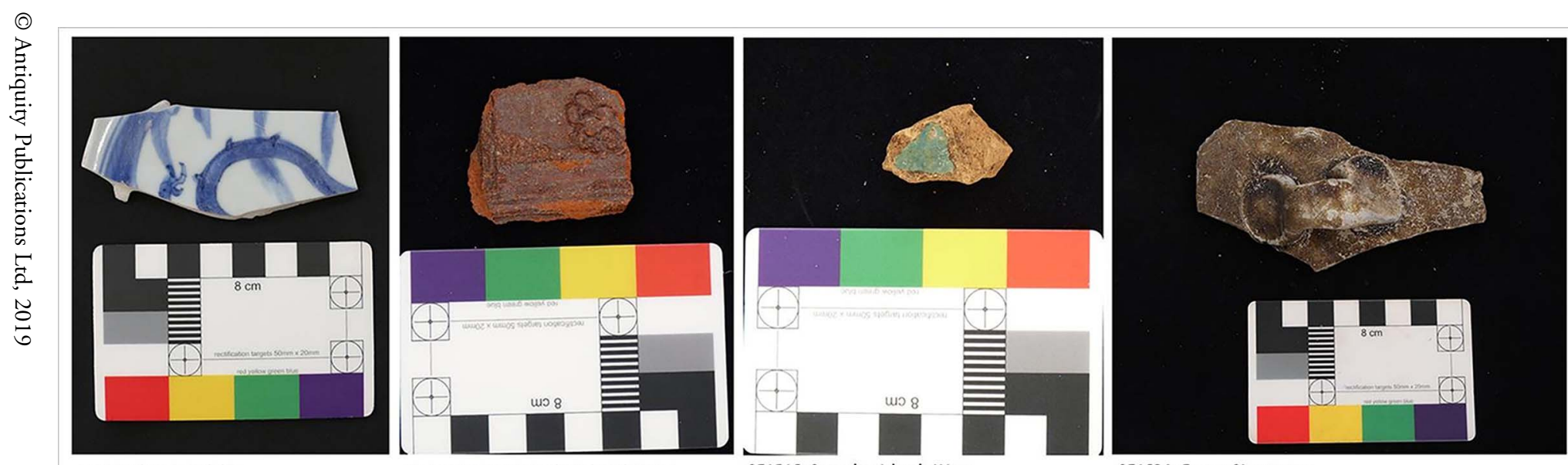

SF14: Ming Porcelain

SF3008: Low Countries Glazed Ware

SF1516: Sasanian Islamic Ware

SF1634: Dusun Stoneware

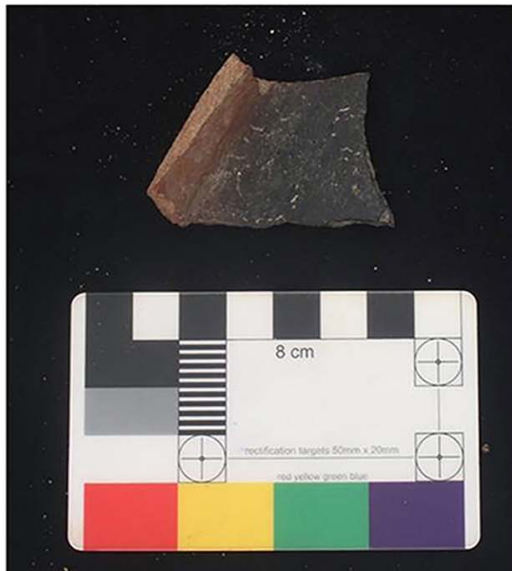

SF1578: Black and Red Ware

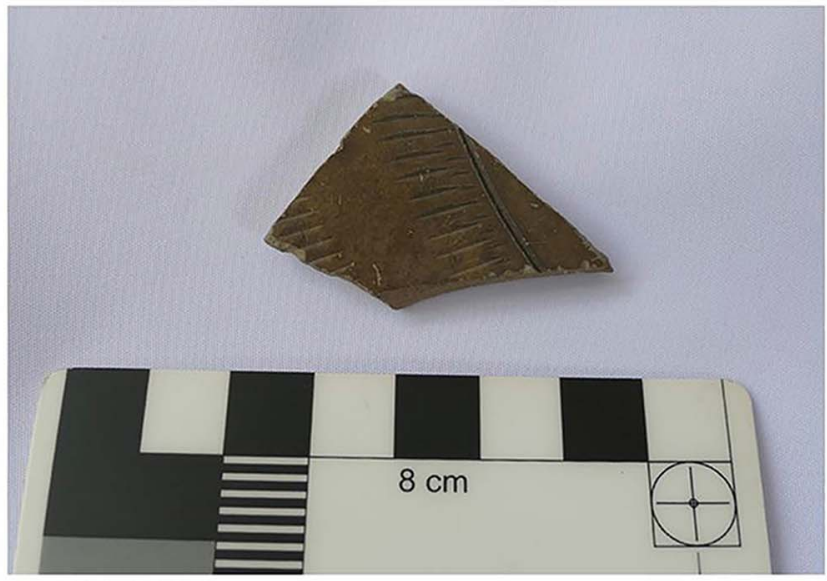

SF4447: Rouletted Ware

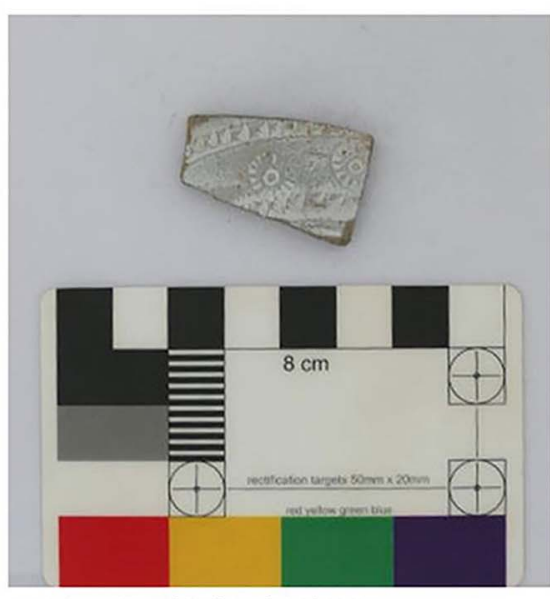

SF1602: Stamped and Rouletted Ware 
Further HEFCE-GCRF-sponsored excavations will investigate the GPR anomalies potentially representing Portuguese-era monuments, and continue to seek secure stratigraphic sequences to provide robust scientifically dated evidence for the origins of Jaffna and its role within the development of international trade and communication networks before and beyond European contact.

\section{Acknowledgements}

The 2017 fieldwork was sponsored by the British Academy (SG162515), the Institute of Medieval and Early Modern Studies (Durham University), with support from the Central Cultural Fund and Department of Archaeology (Government of Sri Lanka), the PGIAR (University of Kelaniya) and the Universities of Jaffna and Durham.

\section{References}

Baldaeus, P. 1703. Description of the great and most famous Isle of Ceylon. London: Awnsham \& John Churchill.

Begley, V. 1996. The ancient port of Arikamedu: new excavations and researches 1989-1992. Paris: Ecole Francais D'Extreme-Orient.

Carswell, J.S.U., S.U. Deraniyagala $\&$ A. Graham. 2013. Mantai: city by the sea. Aichwald: Linden Soft.

Coningham, R.A.E. 2006. Anuradhapura: volume 2: the artefacts. Oxford: Archaeopress.

Coningham, R.A.E., K.P. Acharya, C.E. Davis, K. Weise, R.B. Kunwar \& I.A. Simpson. 2018. Look down, not up: protecting the post-disaster subsurface heritage of the Kathmandu Valley's UNESCO World Heritage Site, in L.A. Bracke, H. Ruszczyk \& T. Robinson (ed.) Evolving narratives of hazard and risk: the Gorkha earthquake, Nepal, 2015: 159-81. Cham: Palgrave Macmillan.

Ford, L.A., A.M. Pollard, R.A.E. Coningham \& B. Stern. 2005. A geochemical investigation of the origin of Rouletted and other related South Asian fine wares. Antiquity 79: 909-20. https://doi.org/10.1017/S0003598X00115030
Mudiyanselage, S.R.P.D. 2011. Sri Lankan archaeological heritage damaged by war: the restoration of the Dutch Fort of Jaffna, in S. Lambert \& C. Rockwell (ed.) Protecting cultural heritage in times of conflict: contributions from the participants of the International Course on First Aid to Cultural Heritage in Times of Conflict: 72-76. Rome: ICCROM.

Nelson, W.A. 1984. The Dutch forts of Sri Lanka. Edinburgh: Canongate.

Pushparatnam, P. 2014. Tourism and monuments of archaeological heritage in northern Sri Lanka. Jaffna: P. Pushparatnam.

- 2015. Nallur Kingdom and Jaffna Fort—a review. Sri Lankan Journal of South Asian Studies 1: 81102.

Ragupathy, P. 1987. Early settlements in Jaffna: an archaeological survey. Madras: Ragupathy.

Rajan, K.V. \& K. Raman. 1994. Kaveripattinam excavations, 1963-73. New Delhi: Archaeological Survey of India, Government of India.

Tomber, R. 2000. Indo-Roman trade: the ceramic evidence from Egypt. Antiquity 74: 624-31. https://doi.org/10.1017/S0003598X00059986

Weisshaar, H.-J., H. Roth \& W. Wijeyapala. 2001. Ancient Ruhuna: Sri Lankan-German archaeological project in the Southern Province. Mainz: Philipp Von Zabern.

Received: 14 November 2018; Accepted: 27 November 2018; Revised: 2 February 2019

(C) Antiquity Publications Ltd, 2019 